\title{
CULTIVATION POSSIBILITY OF GOLDEN OYSTER MUSHROOM (PLEUROTUS CITRINOPILEATUS) UNDER THE EGYPTIAN CONDITIONS
}

\author{
GHADA M. MEDANY
}

\author{
Food Tech. Res. Inst., ARC, Giza, Egypt
}

(Manuscript received 22 March 2014)

\begin{abstract}
Among higher fungi, Pleurotus is well acknowledged as an economically important genus. This may be attributed to its world-wide distribution, its broad adaptability to various conditions. Pleurotus citrinopileatus has a very attractive yellow color, good culinary properties, and has highly appreciated commercial potentials in many countries. This Pleurotus type was newly introduced to Egypt from China. This investigation was carried out to determine the cultivation possibility of this new mushroom type under the domestic conditions using the cheap available agro-wastes throughout three consecutive seasons. Rice straw, wheat straw and sawdust were used as base substrates for growing media formula. Growing parameters such as spawn run (incubation time), pinheads initiation, fruit bodies development (maturation) time, yield and biological efficiency (BE\%) were studied. Main chemical constituents of the P.citrinopileatus were estimated. The yielded fruit bodies were dried either by sun or oven and drying data was recorded. Spawn run time ranged from (18-28), (18-30), (16-26) days for first, second and third season, respectively .Fruit bodies development (maturation) were 6-8 days for all tested media. The total fresh yield ranged from $137-393 \mathrm{~g} / \mathrm{kg}$ wet media with $\mathrm{BE} \%$ of $38-115 \%$ for all media through the tested three seasons. The mixture of rice straw and wheat straw media gave the highest yield, while the sawdust media produced the lowest one. P.citrinopileatus fruit bodies contained $85.90-87.37 \%$ moisture content, $22.84-26.01 \%$ crude protein, $2.59-3.23 \%$ crude fat, $7.76-9.06 \%$ ash and $63.77-65.58 \%$ total carbohydrates on dry weight basis. The fruit bodies required 35- 55 hrs. for sun drying, while they took $9-14$ hrs for oven dehydration. Control and sulfured samples dried either by sun or oven showed superior values for rehydration ratio and sensory characteristics. According to the obtained data it could be recommended that $P$. citrinopileatus cultivation could be spread and encourged using the available materials in Egypt.

Keywords: Pleurotus ctrinoplieatus, golden oyster, growing media, substrate, yield, biological efficiency, drying, rehydration chemical composition.
\end{abstract}

\section{INTRODUCTION}

Mushroom is one of the man's earliest foods which have come to be recognized as highly nutritive food, low in calories, but rich in proteins and certain vitamins. Mushrooms have been a food supplement in various cultures and they are cultivated and eaten for their edibility and delicacy. 
The genus Pleurotus (oyster mushroom) comprises some most popular edible mushrooms due to their favourable organoleptic and medicinal properties, vigorous growth and undemanding cultivation conditions. It can be cultivated on log and a wide variety of agroforestry by-products, weeds and wastes for the production of food, feed, enzymes and medicinal compounds, or for waste degradation and detoxification (Gregori et al., 2007). Cultivation of oyster mushroom (Pleurotus spp.) has increased greatly throughout the world during last few decades and constituted the second largest genus of cultivated mushrooms in the world. Its popularity has been increasing due to the ease of its cultivation on various unfermented lignocellulosic wastes, its high yield potential, high nutritional values, as well as medicinal values (Bandopadhyay, 2013).

A study carried out by Musieba et al (2013) stated that, Pleurotus citrinopileatus mushroom can be an excellent source of micronutrients and antioxidants components. .Also, Rushita et al (2013) declared that, P. citrinopileatus had excellent antidiabetic activity and thus has great potential as an ingredient in natural health products.

Mohamed and Hoo (1994) reported that, grey oyster mushrooms are perishable within 2 to 3 days after harvesting, characterized in browning, liquefaction, loss of moisture, texture, aroma and flavour. Mushrooms are highly perishable and their shelf-life depends on processing, package properties and environmental conditions during storage and distribution (Oliveira et al., 2012). Mushrooms are extremely perishable in nature and may not be kept for more than one day after harvesting at ambient conditions. Drying is one of the important preservation methods employed for storage of mushrooms and dehydrated mushrooms are valuable ingredients in a variety of food formulations such as instant soups, sauces, snacks, pizzas, and meat and rice dishes (Giri and Prasad, 2013).

This study was carried out to determine the possibility of growing Pleurotus citrinopileatus which is newly introduced to Egypt under the domestic climatic conditions and using the locally available agro-wastes. Also investigate the drying aspects of this type of mushroom as a convenient preservation method.

\section{MATERIALS AND METHODS}

\section{Fungal Strain:}

Golden oyster mushroom, Pleurotus citrinopileatus (P096) was obtained from JunCao Research Institute of, Fujian Agricultural \& Forestry Univ.(FAFU), China. The culture was maintained on Potato Dextrose Agar (PDA) medium and stored in 
refrigerator at $5-7{ }^{\circ} \mathrm{C}$ after growth. The culture was used for producing the grain spawn by the convenient method. The prepared spawn was stored at $5^{\circ} \mathrm{C}$ until using them for cultivation.

\section{Media preparation and Cultivation:}

Crushed $(2-3 \mathrm{~cm})$ rice straw and wheat straw as well as sawdust were used sole or combined binary (1:1) as the base of growing media. To each single or binary mixture of the previous cellulosic wastes $20 \%$ wheat bran, $1 \%$ soy bean flour, $2 \%$ calcium carbonate were added and mixed well. The moisture content of the aforementioned media formulae was adjusted to approximately 64\%. Each formula was filled in polypropylene bags ( $1 \mathrm{~kg}$ each) and autoclaved at $121^{\circ} \mathrm{C}$ for 1 hour. After that the sterilized media was cooled down, the bags were inoculated by the previously prepared grain spawn $4 \%(w / w)$, then being incubated at $22-27^{\circ} \mathrm{C}$ for spawn run (mycelium growth).

At the end of spawn run (incubation time) the polypropylene bags were top opened and some holes were made in outer surface and subjected to the fruiting conditions i.e. exposure to scattered light, watering by daily water spraying, good ventilation to be sure to eliminate the dense carbon dioxide in growing rooms. Relative humidity was adjusted to $85-90 \%$ and temperature around $20^{\circ} \mathrm{C}$. Pinheads were allowed to develop to complete basidiomata. When the enrolled margins of the pileus of the mushrooms began to flatten, they were manually harvested and weighed at the same day. The crop was picked in consecutive 3 flushes

Since this mushroom type is newly introduced to Egypt from China and their cultivation techniques are not adopted, so this experiment was carried out in three consecutive trials to get actual and reliable results.

The first season started in 2 Jan. 2011 until 31 March 2011.

The second season started in 12 Dec. 2011 until 14 March 2012.

The third season started in 11 Dec. 2012 until 17 March 2013.

\section{Drying of mushrooms:}

Fresh fruiting bodies of $P$. citrinopileatus mushrooms were preserved by drying Mushroom samples were divided into 3 equal parts, each of which was subjected to one of the following pre-treatments before the dehydration process.

A- Untreated sample (control)

B- Steam blanching at $96 \pm 2{ }^{\circ} \mathrm{C}$ for 5 minutes.

C- Soaking in $0.2 \%$ sodium metabisulfite $\left(\mathrm{Na}_{2} \mathrm{~S}_{2} \mathrm{O}_{5}\right)$ for $10 \mathrm{~min}$. (sulfuring)

All the pretreated mushroom samples were dried by the following methods. 


\section{Sun drying:}

Samples were accurately spread in single layer in wooden trays $(100 \times 50 \times 2.5$ $\mathrm{cm}$ ) and dried in direct sun light. Sun drying was continued until the samples reached a constant weight. Sun drying day was expressed as 10 hours.

\section{Oven dehydration:}

The perforated Stainless Steel trays $(50 \times 50 \times 2 \mathrm{~cm})$ were loaded by pre-treated mushroom samples and dried in an air ventilation oven at $60{ }^{\circ} \mathrm{C}$ for $2 \mathrm{hrs}$, then temperature was reduced to $50^{\circ} \mathrm{C}$. Dehydration was continued until samples reached constant weight.

All dried samples were analyzed immediately after drying for moisture content and rehydration ratio (as fast and good quality parameters for dried products)

\section{Analysis:}

\section{Chemical and physical determinations:}

All determinations were carried out in triplicates. Moisture, crude protein $(\mathrm{N} x$ 6.25), fat, and ash contents were estimated according to the A.O.A.C(2005). Total carbohydrates were calculated by differences. Biological efficiency (BE \%) was calculated using the following equation:

$\mathrm{BE} \%=($ Fresh fruiting bodies $\mathrm{g} /$ dry weight of medium substrate $\mathrm{g}) 100$

Spawn run time, pinheads initiation time and fruit bodies development time in days as well as fruit bodies morphology were recorded for each medium formula.

Rehydration ratio was estimated according to Komanowsky et al. (1970) and Hassan (2002). Drying time and drying ratio of mushroom samples were recorded.

\section{Sensory evaluation:}

The quality attributes (taste, color, odor, texture and appearance) of fresh and dried (after being rehydrated) mushroom samples were organoleptically judged by a group of ten panelists. $100 \mathrm{~g}$ of each sample were sauteed in butter $(10 \mathrm{~g})$, salted then served. as reported by Komanowsky et al. (1970).

\section{Microbilogical test:}

Total microbial count was estimated on both fresh and dried mushrooms immediately after drying. Total microbial count was enumerated on plate count agar medium.

The obtained data throughout the course of this study were expressed as means of replicates and statistically analyzed using ANOVA procedure of the SPSS statistical package at confidence level of $5 \%(0.05)$ (SPSS, 1990). 


\section{RESULTS AND DISCUSSION}

\section{Media moisture content:}

The moisture content of the tested growing media formulae was adjusted approximately $64 \%$ during preparation which actually ranged from $63.94-66.11 \%$ ( Table, 1). Very narrow differences between moisture content values for media formula included in the same season were observed. The moisture content of all media formula was suitable for growing P.citrinopileatus.

Table 1. growing media moisture content \% (fresh weight basis).

\begin{tabular}{|l|c|c|c|}
\hline & $1^{\text {st }}$ season & $2^{\text {nd }}$ season & $3^{\text {rd }}$ season \\
\hline Rice straw & $64.85^{\mathrm{a}}$ & $64.46^{\mathrm{b}}$ & $65.17^{\mathrm{ab}}$ \\
\hline Wheat straw & $65.71^{\mathrm{a}}$ & $65.15^{\mathrm{ab}}$ & $64.91^{\mathrm{ab}}$ \\
\hline Sawdust & $64.34^{\mathrm{a}}$ & $65.06^{\mathrm{ab}}$ & $64.52^{\mathrm{ab}}$ \\
\hline Rice straw + wheat straw & $65.83^{\mathrm{a}}$ & $66.11^{\mathrm{a}}$ & $65.50^{\mathrm{a}}$ \\
\hline Rice straw + sawdust & $64.74^{\mathrm{a}}$ & $65.30^{\mathrm{ab}}$ & $63.94^{\mathrm{c}}$ \\
\hline Wheat straw + sawdust & $64.90^{\mathrm{a}}$ & $65.68^{\mathrm{a}}$ & $65.27^{\mathrm{a}}$ \\
\hline
\end{tabular}

Means within the same column that have different small superscript are significantly different.

\section{Growing parameters:}

Spawn run time (incubation time) of $P$. citrinopileatus grown on different media formulae ranged between (18 and 28), (18 and 30) and (16 and 26) days in the first, second and third season respectively, and was affected by media substrate (Table, 2). Saw dust media showed the longest spawn run time throughout all growing season (28, 30, 26 days), respectively.

Table 2. some growing parameters of $P$. citrinopileatus mushroom.

\begin{tabular}{|l|c|c|c|c|c|c|c|c|c|}
\hline \multirow{2}{*}{} & \multicolumn{3}{|c|}{ Spawn run time (days) } & \multicolumn{2}{c|}{ Pinhead initiation(days) } & \multicolumn{2}{c|}{ Fruit bodies develop (days) } \\
\cline { 2 - 11 } & $\begin{array}{c}1 \text { st } \\
\text { season }\end{array}$ & $\begin{array}{c}2 \text { nd } \\
\text { season }\end{array}$ & $\begin{array}{c}\text { 3rd } \\
\text { season }\end{array}$ & $\begin{array}{c}1 \text { st } \\
\text { season }\end{array}$ & $\begin{array}{c}2 \text { nd } \\
\text { season }\end{array}$ & $\begin{array}{c}3 \text { rd } \\
\text { season }\end{array}$ & $\begin{array}{c}1 \text { st } \\
\text { season }\end{array}$ & $\begin{array}{c}2 \text { nd } \\
\text { season }\end{array}$ & $\begin{array}{c}\text { 3rd } \\
\text { season }\end{array}$ \\
\hline Rice straw & $23^{\mathrm{bc}}$ & $19^{\mathrm{bc}}$ & $21^{\mathrm{bc}}$ & $11^{\mathrm{a}}$ & $10^{\mathrm{b}}$ & $13^{\mathrm{a}}$ & $6^{\mathrm{a}}$ & $7^{\mathrm{a}}$ & $6^{\mathrm{a}}$ \\
\hline Wheat straw & $18^{\mathrm{d}}$ & $20^{\mathrm{bc}}$ & $17^{\mathrm{cd}}$ & $13^{\mathrm{a}}$ & $11^{\mathrm{b}}$ & $13^{\mathrm{a}}$ & $7^{\mathrm{a}}$ & $5^{\mathrm{a}}$ & $7^{\mathrm{a}}$ \\
\hline Sawdust & $28^{\mathrm{a}}$ & $30^{\mathrm{a}}$ & $26^{\mathrm{a}}$ & $15^{\mathrm{a}}$ & $16^{\mathrm{a}}$ & $14^{\mathrm{a}}$ & $6^{\mathrm{a}}$ & $8^{\mathrm{a}}$ & $6^{\mathrm{a}}$ \\
\hline $\begin{array}{l}\text { Rice straw }+ \\
\text { wheat straw }\end{array}$ & $20^{\mathrm{cd}}$ & $18^{\mathrm{c}}$ & $16^{\mathrm{d}}$ & $12^{\mathrm{a}}$ & $10^{\mathrm{b}}$ & $13^{\mathrm{a}}$ & $7^{\mathrm{a}}$ & $7^{\mathrm{a}}$ & $6^{\mathrm{a}}$ \\
\hline $\begin{array}{l}\text { Rice straw }+ \\
\text { sawdust }\end{array}$ & $24^{\mathrm{abc}}$ & $26^{\mathrm{ab}}$ & $25^{\mathrm{ab}}$ & $13^{\mathrm{a}}$ & $11^{\mathrm{b}}$ & $14^{\mathrm{a}}$ & $6^{\mathrm{a}}$ & $6^{\mathrm{a}}$ & $7^{\mathrm{a}}$ \\
\hline $\begin{array}{l}\text { Wheat straw } \\
+ \text { sawdust }\end{array}$ & $25^{\mathrm{ab}}$ & $25^{\mathrm{abc}}$ & $23^{\mathrm{ab}}$ & $11^{\mathrm{a}}$ & $11^{\mathrm{b}}$ & $12^{\mathrm{a}}$ & $6^{\mathrm{a}}$ & $6^{\mathrm{a}}$ & $8^{\mathrm{a}}$ \\
\hline
\end{tabular}

Means within the same column that have different small superscript are significantly different. 
Also, it could be observed that the spawn run time of $P$. citrinopileatus was elongated in the formulae containing sawdust compared to other ones. These results are in accordance to the data obtained by earlier investigators, 17-30 days, Pala et al (2013). The lowest mycelium running rate for saw dust substrate might be due to the presence of different kinds of polyphenolic substances in them as suggested by Wang (1982)

The pinheads formation is the second stage of mycelial growth during cultivation of mushroom. Small pinheads like structures were observed. Pinheads initiation time of $P$. citrinopileatus (after completion of spawn run) ranged from (11$15),(10-16)$ and (12- 14) days for the first, second and third season in succession. No significant differences caused by substrate type concerning pinhead imitation time were detected except with sawdust media in second season only. Generally the pinheads appearance were 29- 46 days after inoculation, the longest period recorded was for the saw dust media and the shortest one was with rice straw and combination of wheat and rice straw media. These results are confirmed by those obtained by Ahmed et al. (2013) who stated that pinhead initiation were 7.6- 10.2 days for Pleurotus spp.

Fruit bodies development from pinheads required 5- 8 days throughout the three seasons with no significant differences. This means that first harvest or picking of $P$. citrinopileatus time( spawn run + pin head initiation + fruit bodies develop days) were 35 - 54 days, sawdust showed the longest period( Table,2). These results are confirmed by data of Pala et al. (2013), who mentioned that 25-49 days were required for P.sajor-caju

\section{Yield and biological efficiency:}

The data represented revealed that, using different media formulae resulted in remarkable differences in yield and subsequently biological efficiency (BE \%) of $P$. citrinopileatus, (Table, 3). Total fresh yield g / kg wet media ranged from 137 to 393 and $\mathrm{BE} \%$ ranged from 38-115 in the first season. Media composed from rice straw

Table 3. Yield $\mathrm{g}$ fresh fruit bodies / $\mathrm{kg}$ wet media and $\mathrm{BE} \%$ of $P$. citrinopileatus.

\begin{tabular}{|l|c|c|c|c|c|c|}
\hline \multirow{2}{*}{} & \multicolumn{2}{|c|}{$1^{\text {st }}$ season } & \multicolumn{2}{c|}{$2^{\text {nd }}$ season } & \multicolumn{2}{c|}{$3^{\text {rd }}$ season } \\
\cline { 2 - 7 } & Yield & $\mathrm{BE} \%$ & Yield $^{\mathrm{n}}$ & $\mathrm{BE} \%$ & Yield & $\mathrm{BE} \%$ \\
\hline Rice straw & $296^{\mathrm{b}}$ & 76.57 & $317^{\mathrm{a}}$ & 89.20 & $270^{\mathrm{c}}$ & 77.52 \\
\hline Wheat straw & $330^{\mathrm{b}}$ & 96.24 & $368^{\mathrm{a}}$ & 105.60 & $345^{\mathrm{b}}$ & 98.32 \\
\hline sawdust & $137^{\mathrm{d}}$ & 38.42 & $159^{\mathrm{c}}$ & 45.51 & $183^{\mathrm{d}}$ & 51.58 \\
\hline Rice straw + wheat straw & $393^{\mathrm{a}}$ & 115.01 & $360^{\mathrm{a}}$ & 106.23 & $386^{\mathrm{a}}$ & 111.88 \\
\hline Rice straw + sawdust & $185^{\mathrm{cd}}$ & 52.47 & $241^{\mathrm{b}}$ & 69.45 & $202^{\mathrm{d}}$ & 56.02 \\
\hline Wheat straw + sawdust & $210^{\mathrm{c}}$ & 59.83 & $195^{\mathrm{bc}}$ & 56.82 & $180^{\mathrm{d}}$ & 51.83 \\
\hline
\end{tabular}

Means within the same column that have different small superscript are significantly different. 
and wheat straw has the highest values and differsed significantly compared to other media, while sawdust showed the lowest values. The same trend was noticed in terms of yield and BE\% throughout second and third seasons being 159-368 g / kg wet media and $45.51-106.23 \%$ respectively, for the second season. The yield and BE\% recorded in the third season ranged between (180-386 g/ kg wet media) and 51.58 $111.88 \%$, respectively. No distinctive trend in yield or $\mathrm{BE} \%$ caused by season was detected.

These results are confirmed by the findings of many authors for oyster mushroom, they stated that BE\% was 56- 95, Ahmed et al,(2013), 85-149 BE\%, Pala et al (2013), 170g/ 120g dry substrate with 141 BE\% for P.citrinopileatus Pandey et al (2012), . Maximum yield of P.citrinopileatus (397.71 g / kg wet substrate) and biological efficiency of $148 \%$ were obtained from bean straw Musieba, et al (2012), 1230.6- $1780.4 \mathrm{~g} / \mathrm{kg}$ dry substrate (123-178 BE\%) for P.citrinopileatus (Bandopadhyay, 2013).

\section{Morphology characteristics:}

Fruit bodies of Pleurotus citrinopileatus grown in clusters have a large number of fruit bodies ranging from 20-39 carpophores (different size) and fine hairy or velvet. Upside of cap has bright yellow to golden color, while down side is white. Cap diameter ranged from $3.0-7.5 \mathrm{~cm}$. Stem is white cylindrical, straight or curved and turned up according to the initiation position with $3.0-6.0 \mathrm{~cm}$. long and $0.3-1.2 \mathrm{~cm}$ in diameter. Flesh is soft and pure white in color. Fruit bodies have a pleasant special smell and taste.

\section{Macronutrients of Pleurotus citrinopileatus:}

The estimated chemical constituents were only done for fruit bodies produced from the third season only. The main components of $P$. citrinopileatus mushroom grown throughout the third season only were represented in table (4). Moisture content of P. citrinopileatus grown on different substrates formulae ranged from 85.90 $-87.37 \%$ without significant differences. Crude protein content fluctuated from 22.84 to $26.01 \%$ (on dry wt.basis), significant differences caused by media substrates were detected.

Table 4. Macronutrients percentage in $P$. citrinopileatus (on dry wt. basis).

\begin{tabular}{|l|c|c|c|c|c|}
\hline & Moisture* & $\begin{array}{c}\text { Crude } \\
\text { protein }\end{array}$ & Crude fat & Ash & Total carb.** \\
\hline Rice straw & $87.37^{\mathrm{a}}$ & $22.84^{\mathrm{c}}$ & $3.17^{\mathrm{a}}$ & $9.06^{\mathrm{a}}$ & 64.93 \\
\hline Wheat straw & $86.54^{\mathrm{a}}$ & $25.28^{\mathrm{ab}}$ & $2.67^{\mathrm{b}}$ & $8.05^{\mathrm{b}}$ & 64.0 \\
\hline sawdust & $85.90^{\mathrm{a}}$ & $24.07^{\mathrm{bc}}$ & $2.59^{\mathrm{b}}$ & $7.76^{\mathrm{b}}$ & 65.58 \\
\hline Rice straw + wheat straw & $87.17^{\mathrm{a}}$ & $23.60^{\mathrm{bc}}$ & $3.23^{\mathrm{a}}$ & $8.89^{\mathrm{a}}$ & 64.28 \\
\hline Rice straw + sawdust & $86.33^{\mathrm{a}}$ & $22.91^{\mathrm{c}}$ & $2.92^{\mathrm{ab}}$ & $8.84^{\mathrm{a}}$ & 65.33 \\
\hline Wheat straw + sawdust & $86.74^{\mathrm{a}}$ & $26.01^{\mathrm{a}}$ & $2.54^{\mathrm{b}}$ & $7.68^{\mathrm{b}}$ & 63.77 \\
\hline
\end{tabular}

Means within the same column having different small superscript are significantly different.

* On fresh weight basis. $\quad * *$ Calculated by differences. 
Crude fat generally represents low content in mushrooms and actually ranged between $2.54-3.23 \%$ in P. citrinopileatus fruit bodies grown on different media. Also, substrate media exhibited negligible differences in ash content of P.citrinopileatus, tht ranged from 7.68-9.06\%. Total carbohydrates were estimated by differences and ranged between 63.77- 65.58\%.

The findings of many authors supported and confirmed the present results. Musieba et al(2013) recorded that, $P$. citrinopileatus contained $22.10 \%$ protein, $1.32 \%$ crude lipid , $20.78 \%$ fiber. Pleurotus citrinopileatus mushroom can be an excellent source of micronutrients and antioxidants components. Bandopadhyay (2013) found that pleurotus spp including P. citrinopileatus contained (on dry weight basis) $16-25 \%$ protein, $19-28 \%$ carbohydrate, about $9 \%$ crude fiber. Another study for Pleurotus spp. revealed that they contained $86-90 \%$ moisture, $28-31.8 \%$ protein, $3.5-4.7 \%$ fat and 8.6- 12.8\% ash on dry weight basis (Ahmed et al., 2013).

\section{Drying parameters of $\boldsymbol{P}$. citrinopileatus:}

Mushrooms are extremely perishable in nature and may not be kept for more than one day after harvesting at ambient conditions. Various physiological and morphological changes occur after harvest, that make these mushrooms unacceptable for consumption, so for long term storage or distribution of mushroom it should be preserved by convenient methods. The drying experiment was only done for fruit bodies grown on the most efficient media which composed from rice straw and wheat straw (1:1) and produced only through the third season. Drying time differed greatly depending on drying method and pretreatment of P.citrinopileatus fruit bodies (table, 5).Sun drying time for control sample ( $35 \mathrm{hrs)} \mathrm{was} \mathrm{the} \mathrm{shortest} \mathrm{one} \mathrm{followed} \mathrm{by}$ sample sulfured by dipping in $\mathrm{Na}_{2} \mathrm{~S}_{2} \mathrm{O}_{5} / 10$ min.(45 hrs),

Table 5. Drying parameters of $P$. citrinopileatus mushroom.

\begin{tabular}{|l|l|l|l|l|l|}
\hline & $\begin{array}{l}\text { Drying time } \\
\text { (hrs) }\end{array}$ & Drying ratio & $\begin{array}{l}\text { Moisture } \\
\text { content\% }\end{array}$ & $\begin{array}{l}\text { Rehydration } \\
\text { ratio }\end{array}$ & $\begin{array}{l}\text { Total microbial } \\
\text { count } \times 10^{3} \mathrm{CFU} / \mathrm{g}\end{array}$ \\
\hline Fresh sample & - & - & 87.17 & 4.8 \\
\hline \multicolumn{6}{|c|}{ Sun drying } \\
\hline Control & 35 & 8.06 & $7.81^{\mathrm{b}}$ & $5.30^{\mathrm{bc}}$ & $2.6^{\mathrm{a}}$ \\
\hline Sulfured & 45 & 8.45 & $8.03^{\mathrm{b}}$ & $4.96^{\mathrm{c}}$ & $2.2^{\mathrm{ab}}$ \\
\hline Steam blanched & 55 & 8.88 & $8.65^{\mathrm{a}}$ & $2.52^{\mathrm{d}}$ & $2.3^{\mathrm{ab}}$ \\
\hline \multicolumn{7}{|l|}{ Oven dehydration } \\
\hline Control & 9 & 8.76 & $6.44^{\mathrm{c}}$ & $5.87^{\mathrm{a}}$ & $2.2^{\mathrm{ab}}$ \\
\hline Sulfured & 11 & 8.93 & $6.57^{\mathrm{c}}$ & $5.60^{\mathrm{ab}}$ & $1.8^{\mathrm{b}}$ \\
\hline Steam blanched & 14 & 9.04 & $6.90^{\mathrm{c}}$ & $2.84^{\mathrm{d}}$ & $2.1^{\mathrm{ab}}$ \\
\hline
\end{tabular}

Means within the same column having different small superscript are significantly different. 
while steam blanched sample required $55 \mathrm{hrs}$. for sun drying. Oven dehydration shortens the drying time to be ranged from 9- $14 \mathrm{hrs}$. with the same trend caused by pretreatment.

These results are confirmed by the findings of many authors. Drying time for the mushrooms differed according to mushroom strain and pre-drying treatments. Sun drying time for P.ostreatus ranged from 35 to $50 \mathrm{hrs}$, while it required between 9-12.5 hrs. for oven dehydration. Untreated sample (control) exhibited lower drying time, while, the pre- treated samples needed a longer drying time with special references to those blanched in different solutions. This may be attributed to the absorbance of much water through the blanching and sulfuring process ( Hassan, 2002). Kulshreshtha et al (2009) observed that, the total drying time decreased upon increasing the temperature for a given drying air velocity and batch size. The gray oyster mushrooms required $5 \mathrm{~h}$ drying at $60^{\circ} \mathrm{C}, 7 \mathrm{~h}$ at $50^{\circ} \mathrm{C}$ and $11 \mathrm{~h}$ at $40^{\circ} \mathrm{C}$ to reach constant weight (Mohamed and Hoo, 1994)

The amount of fresh mushroom required to produce a unit of dried one differed according to drying method and drying pretreatment (Table, 5). Drying ratio ranged from 8.06 - 8.88: 1 for sun drying samples and 8.76- $9.04: 1$ for oven dried ones with slight differences caused by pretreatments. Also it could be observed that regardless pretreatment, sun drying showed lower drying ratio values (more dried yield) than oven dehydration.

These results are in agreement with those obtained by other authors. The drying ratio for P.ostreatus ranged between $(9.16-10.88: 1)$ for sun and oven dried samples. Control sample exhibited a high drying yield (low drying ratio). Pre-drying treatments of mushroom reduced the drying yield. This might be due to the loss of soluble solids by leaching out and/or absorption of water through blanching and sulfuring process (Hassan, 2002).

Moisture content of dried $P$. citrinopileatus samples ranged between 7.81 $8.65 \%$ for sun drying and $6.44-6.90 \%$ for oven dried ones. Blanched sun dried sample had the highest moisture content and differed significantly than the other dried samples. Regardless of pretreatment, oven dried samples had less moisture content compared to sun dried samples. These results are confirmed by the finding obtained by, Hassan,( 2002), 6.2- 7.87\% for P. ostreatus, and Kulshreshtha et al (2009) who recorded that, milky mushroom slices were dried from an initial moisture content of approximately $90 \%$ to the final moisture content of about $10 \%$ in a fluidized bed dryer. 
Rehydration ratio of dried $P$. citrinopileatus seems to be affected greatly by both pretreatment and drying method (table, 5). The rehydration ratio values ranged from 2.52 - 5.87: 1 for all dried samples. Oven dried samples showed higher rehydration ratio compared to sun dried ones. Also, it could be noticed that, control sample had the highest rehydration ratio followed in descending order sulfured samples while, steam blanched sample had the worst rehydration ratio. Kulshreshtha et al. (2009) stated that, higher rehydration ratio indicates better product. The rehydration ratio ranged from 2.563 to 4.015 for different operating conditions. Mohamed and Hoo (1994) revealed that, Increasing drying temperature caused increased firmness of the product probably because the mushrooms dried faster thus the time for the breakdown of the cell structural components like pectin or cellulose were reduced. Hassan(2002) stated that, rehydration ratio reflects the quality attributes of dried products. The high reconstitution values, the more water absorption, which reflects a good quality of dried products. The rehydration ratio was affected mainly by predrying treatments, oven dried samples had higher rehydration ratio compared to sun-dried ones. Among the different strains of dried mushroom, P.ostreatus hydrated higher amounts of water than A.bisporus .In this situation, the rehydration ratios of P.ostreatus reached 6.72:1 and 8.35:1. Giri and Prasad, (2013) recorded that, the rehydration ratio of microwave-vacuum dried mushrooms was significantly greater than air dried samples. This may be because the internal structure of the product remains quite undistorted. Therefore, microwave- vacuum dried (MVD) products tended to have a porous and non-shrunken structure with excellent rehydration capacity

Drying process caused severe reduction in total microbial count counted as colony forming unit( CFU) / g of $P$. citrinopileatus mushroom from $4.8 \times 10^{3} \mathrm{CFU} / \mathrm{g}$ for fresh sample to $\left(1.8-2.6 \times 10^{3} \mathrm{CFU} / \mathrm{g}\right)$ for dried samples. Oven dried samples had lower total microbial counts compared to sun dried ones. This could be attributed to the higher temperature and/ or more hygiene used in oven dehydration than open sun drying. Also sulfured and blanched dried samples either dried by sun or oven showed lower total microbial count compared to control sample. This could be due to the effect of sulfur dioxide on microorganisms in sulfured samples and heat treatment used for blanching prior to drying. These results are in agreement with the finding of Hassan (2002) who recorded that, total microbial counts in P.ostreatus dried samples ranged between $(1.4-1.9)$ and $(1.1-1.5) \mathrm{CFU} \times 10^{3} / \mathrm{g}$ for sun and oven - dried samples, in succession. Lakshmipathy et al, (2013) reported that, open dried mushrooms had a significant higher number of microorganisms than all other dehydrated mushrooms. Higher moisture content of the open dried mushroom 
compared to other drying methods could have influenced the microorganism on the dried mushrooms.

\section{Sensory evaluation:}

The data of quality attributes gathered throughout the panelists (Table, 6) revealed that, fresh samples had the highest values of all tested quality attributes (color, taste, odor texture, appearance) and were significantly different from all other samples. Generally oven dehydrated samples got higher overall acceptability scores compared to sun

Table 6. Sensory evaluation of fresh and dried P. citrinopileatus mushroom.

\begin{tabular}{|c|c|c|c|c|c|c|}
\hline & color & $\begin{array}{c}\text { Taste/flavo } \\
\mathrm{r} \\
\end{array}$ & odor & texture & appearance & $\begin{array}{c}\text { Overall } \\
\text { acceptability }\end{array}$ \\
\hline Fresh sample & $9.5^{\mathrm{a}}$ & $9.2^{\mathrm{a}}$ & $9.0^{\mathrm{a}}$ & $9.2^{\mathrm{a}}$ & $9.5^{\mathrm{a}}$ & 46.4 \\
\hline \multicolumn{7}{|c|}{ Sun drying } \\
\hline Control & $7.3^{\mathrm{c}}$ & $8.1^{\mathrm{b}}$ & $7.0^{c}$ & $7.5^{\mathrm{cd}}$ & $7.5^{\mathrm{b}}$ & 37.4 \\
\hline Sulfured & $8.0^{\mathrm{b}}$ & $7.3^{\mathrm{c}}$ & $7.0^{c}$ & $7.0^{\mathrm{d}}$ & $7.8^{\mathrm{b}}$ & 37.1 \\
\hline $\begin{array}{l}\text { Steam } \\
\text { blanched }\end{array}$ & $3.5^{\mathrm{e}}$ & $5.3^{\mathrm{d}}$ & $6.5^{c}$ & $2.5^{f}$ & $3.3^{c}$ & 21.1 \\
\hline \multicolumn{7}{|c|}{ Oven dehydration } \\
\hline Control & $8.4^{b}$ & $8.5^{\mathrm{b}}$ & $7.6^{\mathrm{b}}$ & $8.5^{\mathrm{b}}$ & $8.0^{\mathrm{b}}$ & 40.5 \\
\hline Sulfured & $8.6^{\mathrm{b}}$ & $7.5^{c}$ & $6.5^{c}$ & $7.8^{c}$ & $8.0^{\mathrm{b}}$ & 38.4 \\
\hline $\begin{array}{l}\text { Steam } \\
\text { blanched }\end{array}$ & $4.5^{d}$ & $5.5^{\mathrm{d}}$ & $4.5^{\mathrm{d}}$ & $3.2^{\mathrm{e}}$ & $2.5^{\mathrm{d}}$ & 20.2 \\
\hline
\end{tabular}

Means within the same column having different small superscript are significantly different.

dried ones. Regarding overall acceptability control oven dehydration got the highest score followed in descending order by sulfured oven dehydrated sample, then both control and sulfured sun dried samples. Meanwhile, blanched samples dried either by sun or oven got the lowest overall acceptability score and were significantly different in all tested quality attributes than the other samples and were unacceptable. No significant differences in color were detected between oven dehydrated control and sulfured samples either dried by oven or sun. Control samples dried by sun or oven got the highest score of taste attribute and differed significantly compared to the other samples. On the other side, blanched samples got the lowest score in all tested quality attributes especially color, appearance and texture.

In this respect many researches supported our present findings. Kulshreshtha et al (2009) found that air drying at a temperature of $50{ }^{\circ} \mathrm{C}$ is better as it gives dried 
product with higher rehydration ratio and higher rehydration fraction, lower shrinkage and better color. Giri and Prasad, (2013) stated that, the microwave-vacuum dried mushrooms were rated much better than air dried products by a sensory panel in terms of appearance, color and overall acceptability

\section{Conclusion}

According to the results obtained throughout the course of this study it could be concluded that, Pleurotus citrinopileatus is a very promising oyster mushroom type due to their attractive color and excellent culinary properties besides their good nutritive characteristics. Successful growing of P.citrinopileatus under domestic conditions in Egypt using the very cheap available agro-wastes was achieved. Most substrates formulae gave satisfactory yield especially the mixture of rice straw and wheat straw. Also drying process is convenient for P.citrinopileatus either by sun or oven for producing a good dried product and expanding their shelf life.

\section{REFERENCES}

1. Ahmed, M., Abdullah , N., Ahmed, K.U. and M.H.M. Borhannuddin Bhuyan. 2013. Nutritional composition of oyster mushroom strains newly introduced in Bangladesh Pesq. agropec. bras., Brasília, 48, (2) 197-202.

2. AOAC. 2005. Official methods of analysis (18th ed.). Published by the Association of Official Analytical Chemist's International, Published by AOAC International suite 500481 North Fredrick Avenue Gaithersburg, Maryland 20877-2417, USA

3. Bandopadhyay, S. 2013. Effect of supplementing rice straw with water hyacinth on the yield and nutritional qualities of oyster mushrooms (Pleurotus spp.). Micologia Aplicada International, 25(2): 15-21.

4. Giri, S.K and Prasad, S. 2013. Quality Characteristics of Microwave-Vacuum Dried Button mushrooms (Agaricus bisporus). Octa. J. Biosci. Vol. 1(1):24-31

5. Gregori, A., M. Svagelj and J. Pohleven. 2007. Cultivation Techniques and medicinal Properties of Pleurotus spp. Food Technol. Biotechnol. 45 (3) 238-249.

6. Hassan, F.R.H., 2002. Studies on the bioconversion of some agricultural wastes using Pleurotus and Agaricus mushrooms. Ph.D. Thesis, Fac. Of Agric., Cairo Univ., Egypt.

7. Komanowsky, M., F.B. Talley and R.K. Eskew. 1970. Air drying of cultivated mushrooms. Food technology 24: 1020-1024. 
8. Kulshreshtha, M., A. Singh and D. Vipul. 2009. Effect of drying conditions on mushroom quality. Journal of Engineering Science and Technology , 4 (1) : 90 98

9. Lakshmipathy,G., A. Jayakumar, M. abhilash and S.P. Raj. 2013. Studies on different drying, canning and value addition techniques for mushrooms (Calocybe Indica). Afr. J. Food Sci., 7 (10): 361- 367.

10. Mohamed, S. and T.S. Hoo. 1994. Effect of Pretreatments on the Characteristics of Dried Grey Oyster Mushroom (Pleurotus sajor - caju).Pertanika J. Trop. Agric. Sci. 17(2): 111-115.

11. Musieba, F. , S. Okoth, R. K. Mibey, S. Wanjiku and K. Moraa. 2012. Suitability of Locally Available Substrates for Cultivation of the Kenyan Indigenous Golden Oyster Mushroom (Pleurotus citrinopileatus Singer). American Journal of Food Technology, 7 (10): 650- 655.

12. Musieba, F. , S. Okoth, R. K. Mibey, S. Wanjiku, K. Moraa. 2013. Proximate Composition, Amino Acids and Vitamins Profile of Pleurotus citrinopileatus Singer: An Indigenous Mushroom in Kenya. American Journal of Food Technology, 8 (3): 200-206.

13. Oliveira, F., M.J. Sousa-Gallagher, P.V. Mahajan and J.A. Teixeira. 2012. Development of shelf-life kinetic model for modified atmosphere packaging of fresh sliced mushrooms. Journal of Food Engineering $111: 466-473$

14. Pala, S. A., A. H. Wani and R.A. Mir. 2013. Evaluation of yield performance of Pleurotus sajor-caju on different agro-based wastes. Afric. j. of Agric. Res. 8,(23): 3025- 3028.

15. Pandey ,, V. K., M. P. Singh, A. K. Srisvastava, S. K. Vishwakarma and s. Takshak. 2012. Biodegradation of sugarcane bagasse by Pleurotus citrinopileatu. Cell. Mol. Biol. 58 (1): 8-14.

16. Rushita, S., M. Vijayakumar, A. Noorlidah, M. Ameen Abdulla and S. Vikineswary. 2013. Effect of Pleurotus citrinoplieatus on blood glucose, insulin and catalase of streptozotocin-induced type2 diabetes mellitus rats. The Journal of Animal \& Plant Sciences, 23 (6): 1566-1571.

17. SPSS. 1990. SPSS /PC for the IBMPC/XI. Chicago, IL. USA.

18. Wang, C.W. 1982. Cellulolytic enzymes of Volvariella volvacea in Tropical Mushrooms Biological Nature and cultivation methods (ed.) S.T. Chang and T.H. Quimio, The Chinese University press, Hong Kong, pp 167- 186. 


\title{
(مكانية تنمية مشروم المحارى الذهبى (بلورتس سترينوبوليتس) تحت الظروف المحلية المصرية
}

\author{
غادة مصطفى مدنى \\ معهُ بحوث تكنولوجيا الاغذية - مركز البحوث الزراعية- الجبزة- مصر
}

يعتبر جنس البلورتس من الأجناس التي تحظي بالأهتمام والتقدير الكبيــر بــين كـلـ الفطريــات

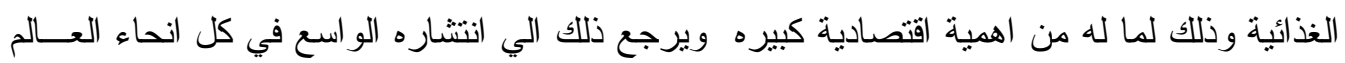

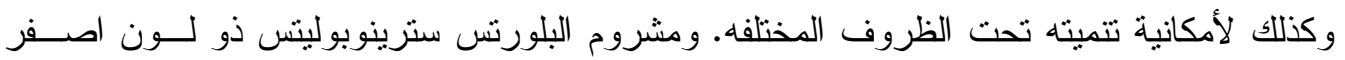

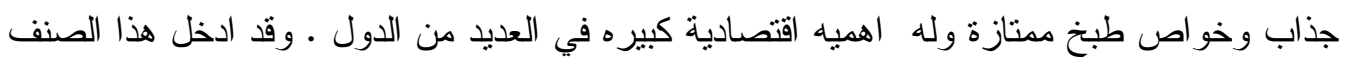

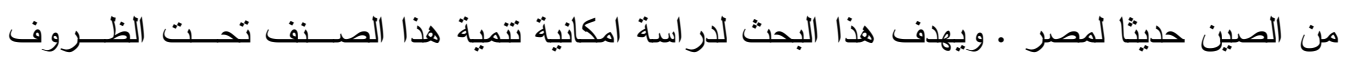
المحلية وباستخدام المخلفات الزر اعية الرخيصة و المتاحة وقد اجريت تللك التجارب في ثلأثنة مو اسم

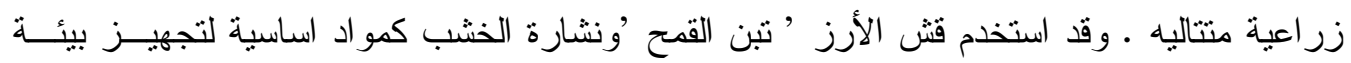

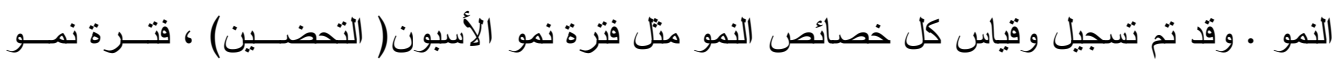
بدايات الثمار ( روؤس الدباييس ) وفترة نضج الثمرة وكذلك الأنتاج الكلي و الكفاءه الحيويه لكل بيئه

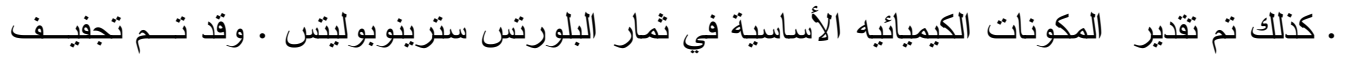

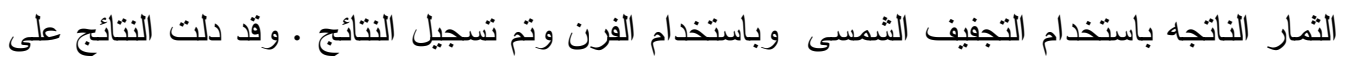

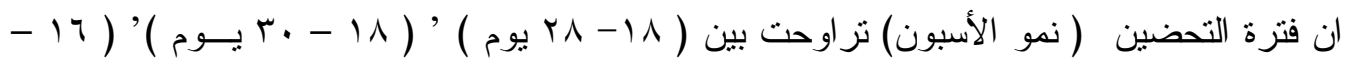

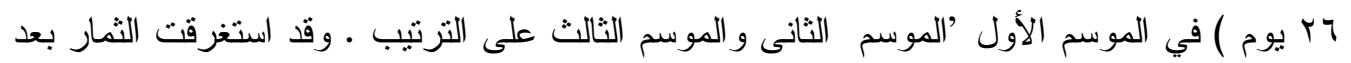

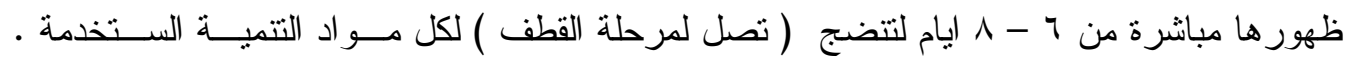

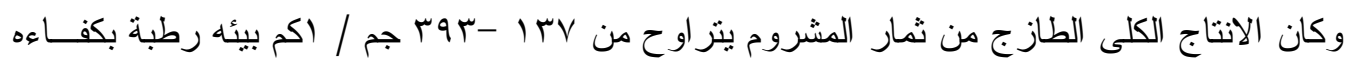

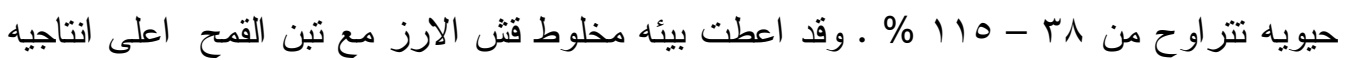

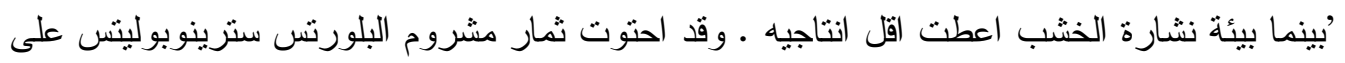
. و و ه - 10 .

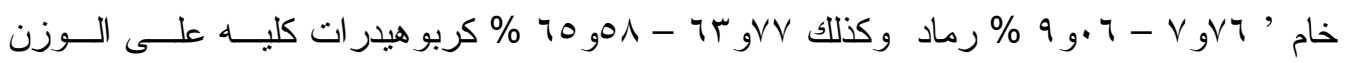

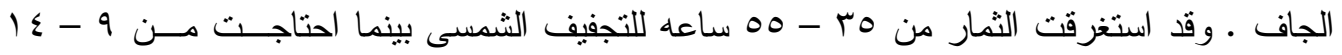

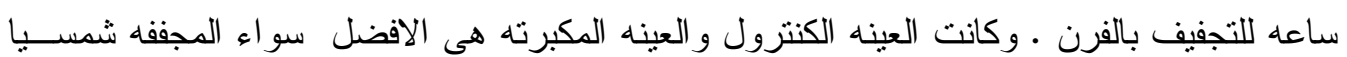
او بالفرن من حيث نسبة الاسترجاع وكل الخواص الحسيه و القبول العام.

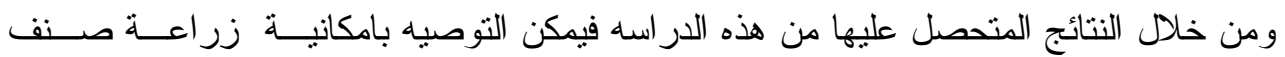

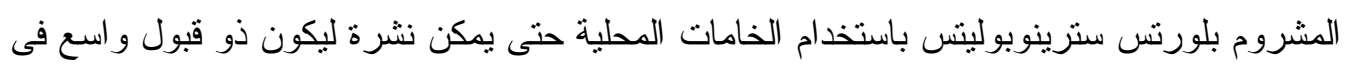

